\title{
Stages of Development of Sberbank as a Reflection of Changes of the State
}

\author{
Oleg Novikova , Aleksey Manenkov ${ }^{b}$, Dagmara Borshchigovac
}

\author{
${ }^{a}$ Associate Professor, Department of Political Sciences, Financial University, Moscow, Russia; OGNovikov@fa.ru \\ ${ }^{\mathrm{b}}$ 2nd-year student, Faculty of International Economic Relations, Financial University, Moscow, Russia; \\ lexmanenk4@gmail.com \\ c 2nd-year student, Faculty of International Economic Relations, Financial University, Moscow, Russia; \\ dagmara.intouch@gmail.com
}

\begin{abstract}
The research team, consisting of a political scientist and two young international finance specialists, made an interdisciplinary investigation on Sberbank to understand the prerequisites of its current state. To achieve this, the authors checked the history, principles of operation and the relationship of Sberbank with different political institutions, including the national state as the main one of these. We discovered that Sberbank changed drastically parallel to the changes of the state - founded as a transparent, stable saving institution during tsarist Russian Empire it absorbed all the controversy of later epochs with its "crescendo" in the 1990s. Much has been already saying about the citizens' deposits, made before 1991 and later claimed "burnt" or "zeroed", but the authors tried to add some arguments trying to represent alternative points of view and calculate the scales of citizens' financial losses. The paper contains the analysis of the most important facts and stages of development of the organisation since the foundation till recent years.
\end{abstract}

Keywords: Sberbank; deposits; Sberbank history

JEL Classification: G21, G28

(c) Oleg Novikov, Aleksey Manenkov, Dagmara Borshchigova, 2020

"A cceptance of small amounts for preservation with an increment of interest through savings for any citizen correctly and profitably to reserve for future needs" ${ }^{1}-$ this phrase emphasised the main goal and indicated the origin of the savings banks (Sberbank is the historical successor of the savings banks), which first appeared in Russia in the 1840s.

Before the Russian Emperor signed this Decree on 12 November 1841, there had been various debates in the highest echelons of power concerning the necessity of this reform. However, the governor was sure that savings banks would be an essential tool of social policy, a way of fostering economy and thrift, taking into account the experience of European countries (the saving institutions first appeared in Scotland

\footnotetext{
${ }^{1}$ Ustav kredytnyi. Svod zakonov Rossiyskoi Imperii. SPb., 1893.
} T.XI. Ch. II. p. 107. and further developed in the West in the late $18^{\text {th }}$ and early $19^{\text {th }}$ centuries). ${ }^{2}$

This degree proclaimed the creation of a new type of banking institutions and, in case of future success, the possibility of spreading this type of institution throughout the whole Empire. Nikolai Christofari, an employee of the Loan Treasury in St. Petersburg, became the first client of the first Russian savings bank. On 1 March 1842, he opened his first deposit in the amount of 10 rubles at 4 per cent per annum since there couldn't be more than 10 rubles on depositor's account. ${ }^{3}$ Moreover, the total amount of deposits from one person could not exceed 300 rubles in silver, since savings banks were mainly focused on people with

${ }^{2}$ Western Bank of Scotland: History. Available at https://www. natwestgroup.com/heritage/companies/western-bank-of-scotland.html// (Accessed 25.11.2020).

${ }^{3}$ History of Sberbank, Sberbank. Available at https://www.sberbank.com/ru/about/history. (Accessed 26.11.2020). 
Table 1

Development of saving banks in Russian in 1865-1892

\begin{tabular}{ccccc}
\hline Year & $\begin{array}{c}\text { Number of } \\
\text { cashboxes }\end{array}$ & $\begin{array}{c}\text { Number of cashbooks, } \\
\text { thousand }\end{array}$ & $\begin{array}{c}\text { Lump-sum contribution, } \\
\text { million rubs. }\end{array}$ & $\begin{array}{c}\text { Loan portfolio savings banks, } \\
\text { million rubs. }\end{array}$ \\
\hline 1865 & 47 & 70.3 & 5.4 & 4.6 \\
1870 & 65 & 74.7 & 4.9 & 5.2 \\
1875 & 75 & 81.9 & 5.5 & 5.4 \\
1880 & 76 & 104.1 & 9.1 & 10.0 \\
1885 & 326 & 218.9 & 26.6 & 28.0 \\
1890 & 1826 & 798.4 & 147.0 & 142.0 \\
1895 & 3875 & 1907.0 & 367.9 & 336.7 \\
\hline
\end{tabular}

Source: Petrov Y. A, Kalmykov S.V. (1995). Savings bank business in Russia. Moscow: K.I.T.

low income. So the owners of significant capital were deprived of the opportunity to make profits at the expense of the state.

During the first year of the operation, the saving bank in Moscow conducted 2.5 thousand transactions and 15.5 thousand rubles were attracted. In 1853 the amount of contributions to savings banks increased up to 50 rubles, and the maximum deposit amount to 750 rubles, respectively. Consequently, by the end of 1860 , there had been more than 90 thousand depositors, and the balance of cash deposits in the capital's cash offices exceeded 6 million rubles.

In 1860, the unified Bank of Russia was established, and saving institutions were transferred to the Ministry of Finance's jurisdiction. On 16 October 1862, Alexander II adopted a new Charter of savings banks, according to which they had to be created "in all cities, townships and places.” As a result, from 2 small institutions with 20 employees in St. Petersburg and Moscow, the cashboxes turned into a network operating throughout the country. By 1895, 3875 branches were opened, 368 million rubles were accumulated in deposits. This time is called the heyday of Russian banking. The results 1865-1892 we shown in Table 1.

The further development of savings banks is tightly connected with the monetary reform of 1895-1897, initiated by S.U. Witte, who managed to transfer the ruble to the gold standard, even though this move caused much criticism. ${ }^{4}$ He believed that

\footnotetext{
${ }^{4}$ Pushkareva I. M., Stepanov A.S. The "Golden" ruble in the
} Russian monetary system in 1897-1917. savings banks in Russia should remain state-owned and be a part of the state financial system.

On 1 June 1895, Nicholas II approved a new charter of savings banks proposed by the State Council and prepared by Minister Witte. Under the new charter as the basis for the activities of the savings banks, French savings model was chosen, which Witte, who had financial affairs with French bankers, considered to be the most successful and acceptable for Russia. The government assumed responsibility for the integrity and safety of the amounts and capital transferred to the cash desks. Contributors can be "persons of both sexes, any rank and age”, as well as institutions and communities. Deposits were accepted for an amount not exceeding 1 thousand rubles. For one depositor and no more than 3 thousand rubles. For an institution or society. ${ }^{5}$

After the introduction of the new charter, the ultimate goal of the government was to expand the network of cashboxes, aimed at the attraction to saving people with low financial literacy. In 1897, actions were taken to revive the factory cash registers. In the charter of the Office of Savings Banks was mentioned: "The workers who have accumulated savings and therefore who value their position, represent a reliable counterbalance to any kind of agitations. Accustoming workers to saving make them hard work and facilitates the in the labour level and economic welfare."

In 1900-1902, savings banks were opened at the state and private railways. Savings operations

\footnotetext{
${ }^{5}$ Russkie banki. Spravochnik I statisticheskie svedeniy o vseh deistvuyshih v Rossii gosudarstvennyh, chastnyh I obshestvennyh kredytnyh uchrejdeniyah na 1 January1895. p. 6.
} 
could be carried out not only in urban centres but also in remote areas (for example, in Siberia). Since the early 1900s, cash desks have been opened in secondary schools to instil a thrift spirit in them from childhood. By 1914, Russia had 2.5 thousand school ticket offices: 359 in secondary schools and 1385 in the lowest. More than $10 \%$ of the students were depositors.

During the first decade of the Witte's reforms, Russia took a huge step forward. For instance, the number of cash registers increased by $2.5-3$ times, whereas the number of purchased securities by nine times. Savings business in Russia outstripped the European results, and before World War I, the savings bank system of Russia experienced a period of flourishing (Table 2).

During the war years, the government paid particular attention to the development of savings banks. In difficult wartime conditions, several steps had been taken in order to maximise the expansion of savings institutions. A crucial role played the law of 23 October 1915, providing for the expansion of the network of postal and telegraph departments with the opening of savings banks in the countryside. In less than a year and a half after its adoption (before the February Revolution of 1917), more than 4970 cashboxes had been opened. Moreover, first cashboxes were opened in China, Mongolia, Iran, as well as in Russian embassies in the USA and Canada. Considering possible options for expanding the network of savings institutions parishes and clergy were also involved in the savings business since there were more than 40 thousand Orthodox churches throughout the whole Empire.

In October 1921, the All-Russian Central Executive Committee adopted the establishment of the State Bank. On 26 December 1922, a resolution of the Council of People's Commissars was adopted on the establishment of state savings banks. The social composition of donors as of 1 October 1927 shows that the largest percentage (46.6\%) falls on the employees of the Council, followed by workers (21.4\%), persons of the free professions (2.9\%), peasants $(2,1 \%)$. The peasantry remained practically not covered by savings banks. Overall, the number of savings banks increased 40 times, depositors' accounts -36 times, the volume of deposits -105 times.

During the World War II reserves, free financial resources of farms and banks, as well as funds of the population in the amount of 270 billion rubles were directed to the defence needs. Throughout the 1941-1943 period number of deposits increased by seven times, and the sum of deposits reached 1425.5 billion rubles, considering that in July-December 1941 new banknotes had been emitted with the overall result of 14.3 billion rubles. ${ }^{6}$

The first post-war years were characterised by the extremely rapid growth of operations by savings institutions, with the deposit as the main instrument. Obviously, savings operations grew more intensively in the cities: $123 \%$ growth versus $54 \%$ in rural areas.

In 1960-1980 the development of savings bank systems carried on. On 1 January 1963, the Council of Ministers of the USSR entrusted the State Bank USSR organisation of savings business. It transferred the entire system of savings banks from the Ministry to its jurisdiction. The data in Table 3 characterise development savings business in the USSR during this period.

This table illustrates that throughout this period the number of cashboxes increased by 18 per cent, number of deposits by 3.1 times whereas the sum of deposits by 18.5 times, respectively (even though there was a severe denomination in 1961 where the "Khrushchev candy wrappers" had been introduced).

Thus, the analysis of the development of the savings business in the Soviet period shows that the savings infrastructure was steadily improving, which in turn facilitated the process of attracting more depositors and the amount of deposits. At the beginning of 1979, population deposits exceeded 130 billion rubles, and the savings banks received 50 per cent of the population's incomes. ${ }^{7}$

During the perestroika period in 1987, there was a reorganisation of the banking system. In 1988 new banks such as State Bank, Vnesheconombank, Promstroy Bank of the USSR, AgroIndustrial Bank of the USSR, Zhilsotsbank USSR and Sberbank of the USSR appeared. By the beginning of 1988, the system of Sberbank of the USSR included 15 republican banks, 166 regional, 4.1 thousand departments with 50.7 thousand branches and 22.1 thousand agencies, and by mid-1990 each

\footnotetext{
${ }^{6}$ Nikolai Voznesensky, The military economy of the USSR during the Patriotic War.

${ }^{7}$ Kashin Y. I Savings rate in the USSR. AM: Finances, 1979, p 5.
} 
Table 2

Saving bank before World War I

\begin{tabular}{cccccc}
\hline Year & Number of & & $\begin{array}{l}\text { Number of } \\
\text { cashbooks, } \\
\text { cashboxes }\end{array}$ & & \multicolumn{2}{c}{\begin{tabular}{c} 
Lump-sum contribution, million rubs. \\
\cline { 5 - 6 } thousands
\end{tabular}} & cash & Loan portfolio \\
securities & $\begin{array}{c}\text { Lovings banks, } \\
\text { million rubs. }\end{array}$ \\
\hline 1895 & 3875 & 1907 & 367.9 & 33.8 & 336.7 \\
1900 & 5415 & 3551 & 661.9 & 90.0 & 676.3 \\
1904 & 6558 & 5127 & 910.6 & 195.1 & 941.9 \\
1906 & 6679 & 5665 & 1035.0 & 237.4 & 1122.1 \\
1910 & 7365 & 7436 & 1396.9 & 286.9 & 1582.9 \\
1913 & 8553 & 8992 & 1685.4 & 348.6 & 1741.4 \\
\hline
\end{tabular}

Source: Outline of development and activities of state savings banks. SPb. 1912.

Table 3

The development of saving business in the USSR (1959-1984)

\begin{tabular}{ccccccc}
\hline Item & 1959 & 1960 & 1970 & 1975 & 1980 & 1984 \\
\hline Number of cashboxes, th & 54.3 & 66.5 & 78.3 & 79.9 & 79.9 & 78.9 \\
Number of deposits, mln rubs & 47 & 52.2 & 80.1 & 106.6 & 142.1 & 164.0 \\
Sum of deposits, mln rub & 87 & 10.9 & 46.6 & 91.0 & 156.5 & 202.1 \\
\hline
\end{tabular}

Source: The economy of the USSR for 60 years. JUB. Statistical collection. Moscow. 1977, p. 462.

administration district had a bank with subordinate from 15 to 40 branches. $^{8}$

\section{0-1998}

During the collapse of the USSR and the formation of the Russian Federation, Sberbank remained the leading institution that accumulated citizens' money. It was a controversial period, since Sberbank was considered state property and then became a Joint Stock Company, according to some beliefs, Sberbank is not obliged to bear any past debts. In contrast, others consider the history of Sberbank as a whole if the one financial institution. Both points of view are still regarded as unofficial. It was a painful period for the population: the collapse of the Union, "shock therapy" (monetary reforms and inflation), devaluation of the ruble and subsequently national currency denomination. Nowadays, the status of the deposits of the USSR popula-

${ }^{8}$ United Savings business, Ed. R.V. Korneev. MS: Statistics, 1992, p. 21. tion is still to be discussed, and, moreover, in Russia, these deposits are called "burnt". To understand the basis for this thesis, it is necessary to trace in detail the causes and consequences of the reforms that took place in the 1990s.

In July 1990 the Russian republican bank of the Sberbank of the USSR was declared the property of Russian Soviet Federative Socialistic Republic. A planned economic system characterised the Soviet Union. The military industry accounted for vast volumes of production, while production of group "B" products was developed according to the leftover principle, which resulted in a shortage of consumer goods. The accumulation of savings of the population was constantly increasing, but there was nothing to buy. According to the World Bank, ${ }^{9}$ in 1990 Russia's GDP was $\$ 516.8$ billion, while the deposits of citizens accumulated by 1990 in the USSR Savings

\footnotetext{
${ }^{9}$ World Bank National Accounts Data and data files on OECD national accounts. Available at https://data.worldbank.org/ indicator/NY.GDP.MKTP.CD? Locale=ru \&locations=RU. (Accessed 23.11.2020)
} 


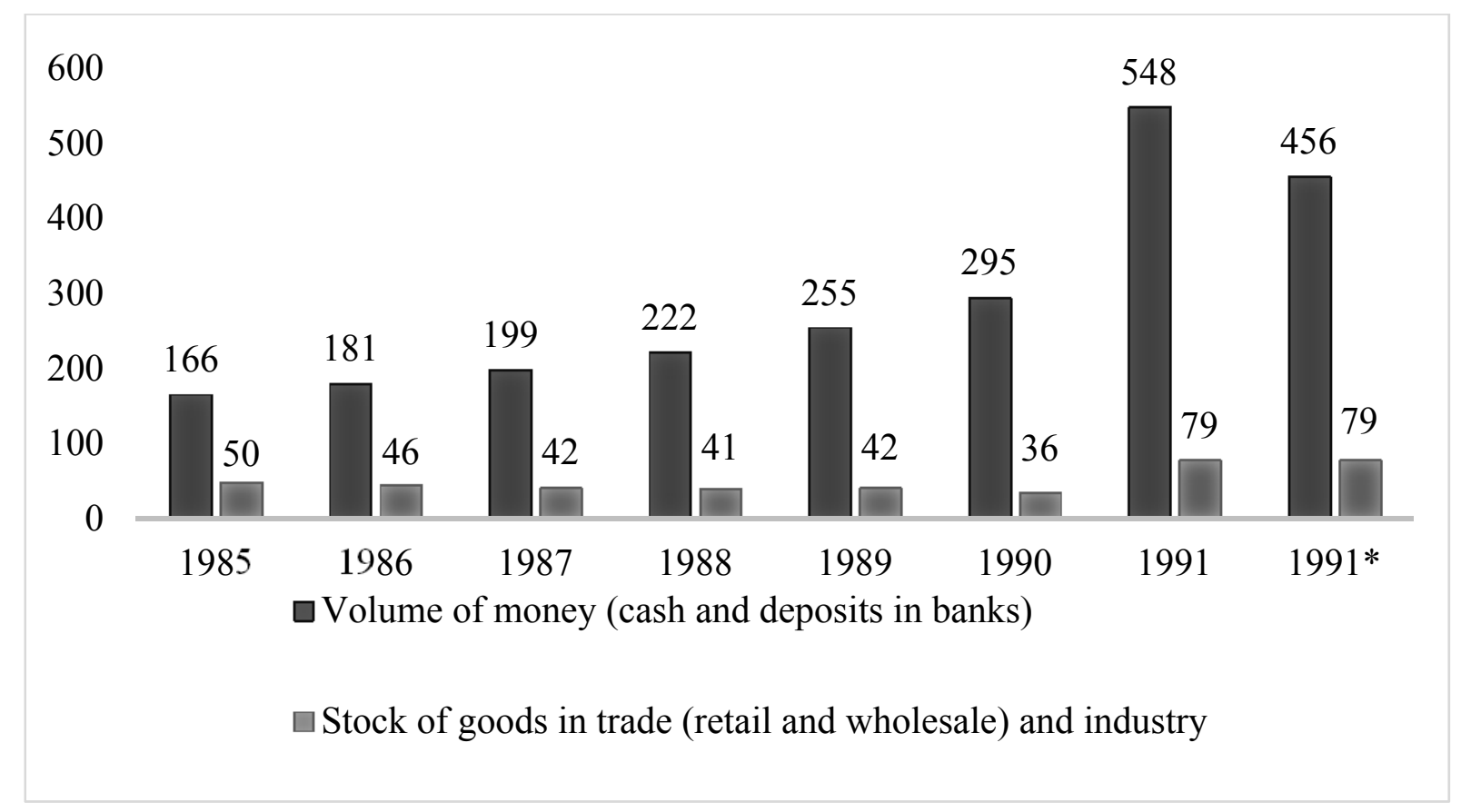

Figure 1. The ratios of the population's money and stocks of goods in trade and industry in Russia (at the end of the year, billion rubles)

Source: National Economy of the RSFSR in 1989; National Economy of the RSFSR in 1990; Social development of the Russian Federation 1992; Russian statistical book 1995; Russian statistical yearbook 1996.

Bank (369 billion rubles) ${ }^{10}$ amounted to 40 per cent of GDP. It was enormous. The explanation is that the Savings Bank of the USSR was the only bank for keeping savings; therefore, all deposits of the population were stored in it. To finance the deficit of the Union's budget, the Government of Nikolai Ryzhkov withdrew citizens' savings from Sberbank. By governmental Decree ${ }^{11}$ of 11 December 1990, the USSR Supreme Soviet instructed the USSR Council of Ministers until 31 December 1991 to properly formalise the debt to Sberbank. It was the end of 1990 when the country faced a monetary (un)balance of the market. The ratios of the population's money and stocks of goods in trade and industry were disproportional (Fig. 1). Stocks of goods in trade and industry in relation to the funds of the population amounted to 12 kopecks per 1 ruble.

To regulate the volume of the money supply, it was necessary to withdraw part of it. It happened

\footnotetext{
${ }^{10}$ Sharionov, A.N. The state is in debt: how the savings of citizens in the Savings Bank of the USSR were destroyed accounts. [Electronic resource]. - URL: https://www.forbes.ru// mneniya-column/makroekonomika/238749-gosudarstvo-vdolgu-kak-unichtozhili-sberezheniya-grazhdan-v-sb // (Accessed 27.11.2020)

${ }^{11}$ Resolution of Supreme Council of the USSR "On the implementation of the law of the USSR "On the state bank of the USSR" and the law of the USSR "On banks and banking activities”" 11 December 1990 No. 1830-1.
}

in January 1991 through the confiscation reform of the Minister of Finance, and from 14.01.1991 - the Prime Minister of the USSR Valentin Pavlov. On 22 January, the last Soviet monetary reform began, the formal reason for which was stated as the fight against counterfeit banknotes - it was announced that counterfeiters had introduced large counterfeit bills of 50 and 100 rubles into cashflow circulation in large quantities. On 22 January 1991, the President of the USSR Mikhail Gorbachev signed a Decree ${ }^{12}$ "On the termination of the acceptance for payment of banknotes of the State Bank of the USSR in denominations of 50 and 100 rubles of the sample of 1961 and the limitation of the issuance of cash from deposits of citizens." This Decree confirmed the Resolution ${ }^{13}$ of the USSR Cabinet of Ministers, which introduced restrictions: old bills had to be exchanged for new ones within three days from 23 January to 25 , but the maximum amount

\footnotetext{
${ }^{12}$ Decree of the President of the USSR of January 22, 1991 No. UP-1329 "On the termination of the acceptance for payment of banknotes of the State Bank of the USSR in denominations of 50 and 100 rubles of the 1961 model and the restriction of the issuance of cash from the deposits of citizens".

${ }^{13}$ Decree dated January 22, 1991 No. 20 "On termination of acceptance for payment of banknotes State Bank of the USSR in denominations of 50 and 100 rubles sample 1961 and the procedure for their exchange and restrictions on issuance cash from deposits of citizens".
} 


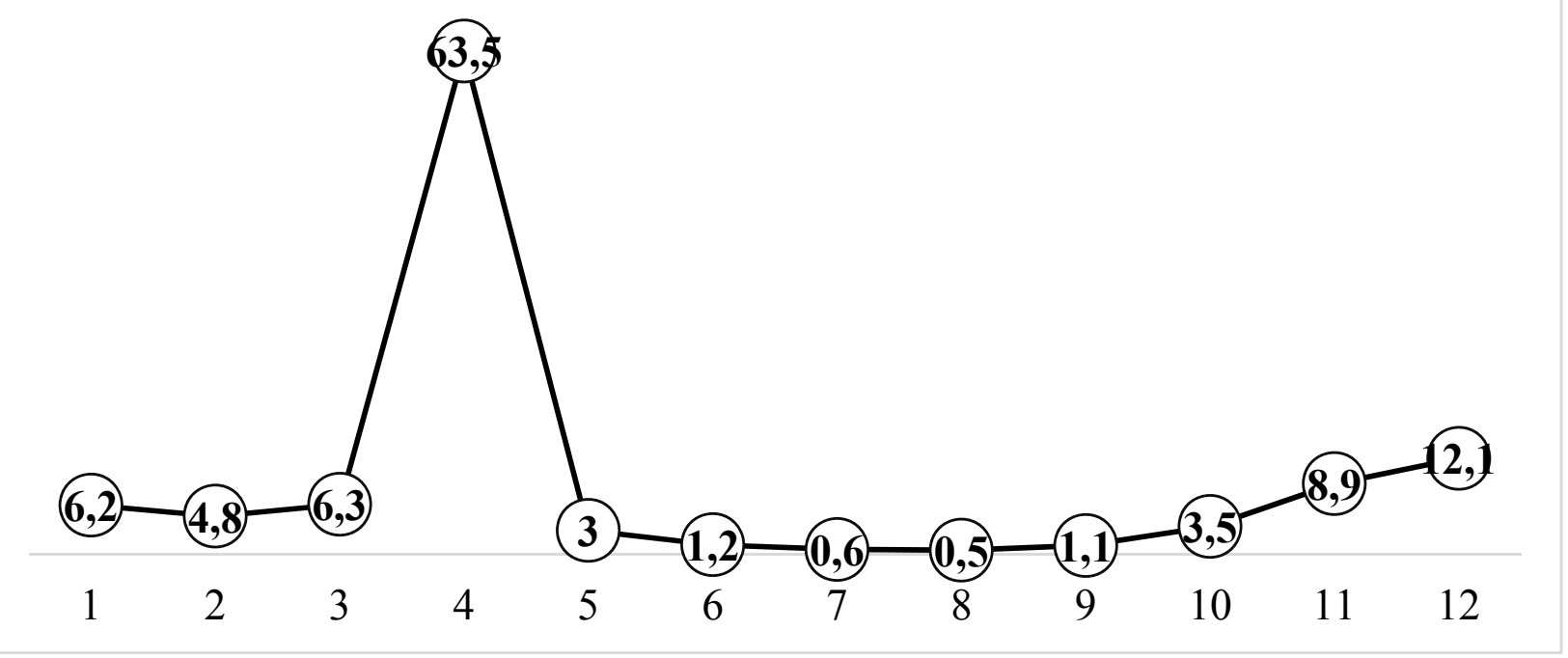

Figure 2. Inflation rate by months in 1990

Source: Inflation rate table by month on an annualised basis. Available at https://уровень-инфляции.рф/таблицы-инфляции. (Accessed 28.11.2020).

of exchange per person was 1000 rubles. It means that the rest of the savings became invalid. The money that was kept on deposits in the Savings Bank was partially "frozen" - one person could withdraw only 500 rubles once a month. The notes on the withdrawn amounts were recorded in the passport since citizens could have deposits in several savings banks in different cities.

In March 1991, "shock therapy" began - an increase in prices by a Decree ${ }^{14}$ of the Council of Ministers of the RSFSR. The changes also affected Sberbank: on 22 March, Gorbachov signed a Decree ${ }^{15}$ concerning the removal of all restrictions on the withdrawal of cash from bank accounts. The same Decree stated the compensation for losses of Sberbank's depositors - to index deposits by 40 per cent. If the monetary equivalent of indexation exceeded 200 rubles, the excess was recorded in a special account, from which money could be withdrawn after three years passed. From the same day, Sberbank was not considered to be the property of the RSFSR, because, according to the Law ${ }^{16}$ of the RSFSR "On Banks and Banking Activities in the RSFSR” dated 2 December 1990,

\footnotetext{
${ }^{14}$ Council of Ministers of the RSFSR Resolution of March 20, 1991 No. 162 "On the reform of retail prices and social protection of the population of the RSFSR".

${ }^{15}$ Decree of the President of the USSR from 22.03.1991, No. UP-1708 "On compensation to the population for losses from the depreciation of savings in connection with a one-time increase in retail prices".

${ }^{16}$ Federal Law "On Banks and Banking Activities" dated 02.12.1990 No. 395-1.
}

at the general meeting of shareholders the JointStock Commercial Savings Bank of the Russian Federation was established.

Viktor Gerashchenko, who was the head of the State Bank of the USSR, in the Letter ${ }^{17}$ dated 15 April 1991, informed the government that the State Bank had begun charging compensations for the government's use of deposit resources (including money received from Sberbank) at 5 per cent per annum. In April, the official inflation rate was 63.5 per cent (Fig. 2 ). Because of the high inflation and the low compensations' interest, the real interest rate on savings confiscated from citizens turned out to be strongly negative from the very beginning. The resolution of the Supreme Council on the debt to Sberbank was not executed by 31.12.1991, because de-facto compensation payments on USSR deposits are still being paid to Russian / ex-Soviet citizens.

December 1991. The authorities have entirely stopped regulating prices. At the end of December, the Soviet Union collapsed, and the state mechanisms for regulating the economy stopped working. The Government did not regulate deposits and their use.

1992-1995. Prices ceased to be regulated, and hyperinflation began.

May 1995. One year before the presidential election, B.N. Yeltsin's ratings, according to official data, was about 3 per cent, and to increase it, the

\footnotetext{
${ }^{17}$ State Bank of the USSR Resolution of 15.04.1991 "On the payment of the state internal debt”.
} 
state promised to restore savings that were stored in Soviet savings banks - and taking into account their purchasing power at the time of investment.

May 1996. Sberbank depositors born before 1916 were paid "preliminary" compensation. Unfortunately, the percentage ${ }^{18}$ of the population born in those years (2.2 per cent or $3.3 \mathrm{mln}$ people) was extremely low, because the life expectancy in the Russian Federation in 1996 was 65.85 years and because of the historical events that people born before 1916 faced up the First World War, two revolutions, civil war, several significant waves of repressions and several other wars: SovietFinnish, and World War II. Those compensations amounted at a maximum of 1 million rubles - it was about $\$ 200$, way far from being generous even at that time. It was a price of either half of a colour TV or two vacuum cleaners. The issue of the promised full compensation was postponed for an undefined period.

Since 1996 shares of Sberbank of Russia have been quoted on the Russian stock exchanges MICEX and RTS. Also, the shareholders' meeting adopted the concept of the bank's development until 2000 that was aimed at transforming the bank into a universal commercial one. The first payment cards were issued, and the Sberbank Non-State Pension Fund was created.

January 1998. The denomination took place a decrease in the nomination value of banknotes and prices by 1000 times or, people simply call it "the crossing of three zeros". A thousand rubles turned into a ruble, that is why Soviet deposits are called "zeroed".

In the 2000s, the procedure for paying compensation and the age of the depositors receiving them changed several times. The current rules ${ }^{19}$ were introduced in 2012 and later modified in 2019. Still, many compensations have not yet been paid. However, the real value of these compensations matches the nominal value of initial deposits, while the real rate of value was a thousand times higher. According to the Draft ${ }^{20}$ of Russian Budget for 2021-2023, the internal debt of the state on USSR deposits

\footnotetext{
${ }^{18}$ Mortality of the population: trends, methods of study, forecasts: Collection of articles. (2007). Denisenko M. B., Bakhmetova G. Sh., (Eds.). Moscow: MAKS Press. pp. 256-271.

${ }^{19}$ Federal Law of 29.11.2018 No. 459-FZ (as amended on 02.12.2019) "On the federal budget for 2019 and for the planning period of 2020 and 2021".

${ }^{20}$ Bill No. 1027743-7 "On the federal budget for 2021 and for the planning period 2022 and 2023".
}

is estimated at 45.4 trillion rubles in 2020, 47.22 trillion rubles in 2021 and 49.11 trillion rubles in 2022 - this is half of Russia's GDP ${ }^{21}$ (110 trillion rubles) that is still impossible to pay back.

Due to the inflation and the failure to implement the policy of indexation of Soviet deposits, payments of these deposits and compensation payments on them, the nominal values of deposits, even if they were not changed, their real value decreased several thousand times. Since Sberbank became non-state property on 03/22/1991 and until the purchase by the Government of the Russian Federation on 03/18/2020, formally, it was only an intermediary financial institute between the population and state that was and still is indebted to depositors. The issue of so called "burnt" deposits remains unsolved up to nowadays.

\section{Practical Examples of Calculating the Compensation on "Burnt Deposits" and Comparison of its Real Value in USD Currency}

Sberbank has a webpage ${ }^{22}$ with a deposit compensation calculator where all criteria are mentioned. pays compensations only for deposits that were made in the USSR Savings Bank on the territory of the current Russian Federation. The restrictions for the deposit: it should be opened before 20 June, 1991 - this is the day of the liquidation of the USSR Savings Bank - and the deposit should remain opened from 20 June, 1991 until 31 December, 1991.

The basis amount for the calculation is the amount that was on the account on 20 June, 1991.

The formula of calculations of a current compensation:

Compensation $=($ Deposit balance as of 20 June 1991) $\times($ Age coefficient $) \times($ Deposit closing date coefficient)

Age coefficient - if the recipient of compensation was born before 1945 , then the deposit amount is multiplied by 3 , if after - by 2 (Table 4 ).

Deposit closing date coefficient - the earlier you withdraw all the money, the lower the coefficient is (Table 5).

\footnotetext{
${ }^{21}$ Statistics showcase: GDP at market prices according to 2008 SNA methodology. Available at https://showdata.gks.ru/report/280029. (Accessed 27.11.2020).

${ }^{22}$ Compensation for deposits. Available at https://www.sberbank.ru/ru/person/contributions/compensation. (Accessed 27.11.2020).
} 


\section{Example 1}

The citizen was born in 1960 and deposited 3,000 rubles in May 1991. He did not make any other payments. The deposit was closed in 1994.

Compensation $=3,000 \times 2 \times 0.8=4,800$ rubles.

The real value of the deposit was 83,625 times more than the real value of compensation.

Example 2

A citizen born in 1943 opened a deposit in Sberbank in May 1991. At the end of April 1991, he put 6,000 rubles in and did not close it. Additionally, he put 500 rubles in May 1991. In 2009 he received 2,000 rubles under the then compensation rules.

Compensation $=6,500 \times 3 \times 1-2000=17,500$ rubles.

The real value of the deposit was 49,7 times more than the real value of compensation.

Example 3

A citizen born in 1943 opened a deposit in 1980. By March 1991, 6000 rubles had been accumulated on the book, and he closed the deposit in 1994. It should be borne in mind that in March 1991, the depositor was automatically compensated (on 22 March Gorbachev signed a Decree) - indexation by $40 \%$ from 6,000 rubles, that is, 2,400 rubles. At the same time, 200 of them were added to the existing account there were 6,200 rubles. And for the remaining 2,200 rubles, a special account was opened. Therefore, on 20 June 1991, the depositor had two accounts - for 6,200 and 2,200 rubles, a total of 8,400 rubles. Compensation will be calculated from this amount. Compensation $=$ $=8,400 \times 3 \times 0.8=20,160$ rubles .

The real value of the deposit was 55 times more than the real value of compensation.

\section{8-2019}

Sberbank's 2000 report stated that lending to the real sector of the economy remains the strategic line of the bank's development. The main borrower of the Bank in 2000 was RAO UES of Russia, a monopoly in the generation and energy transportation headed by Anatoly Chubais. This enterprise attracted more than $\$ 200$ million $^{23}$ and was subsequently liquidated. Afterwards, on its place so-called "natural

\footnotetext{
${ }^{23}$ Sberbank opened a loan to RAO “UES of Russia”. Kommersant. Available at https://www.kommersant.ru/doc/152456. (Accessed 28.11.2020).
}

Table 4

Age coefficient on USSR deposit compensation

\begin{tabular}{cc} 
Year of birth & Coefficient \\
\hline before 1945 & 3 \\
after1945 & 2 \\
\hline
\end{tabular}

Table 5

Deposit closing date coefficient on USSR deposit compensation

\begin{tabular}{cc}
\hline Year of the deposit closure & Coefficient \\
\hline 1992 & 0.6 \\
1993 & 0.7 \\
1994 & 0.8 \\
1995 & 0.9 \\
1996 and later, including still \\
opened deposits
\end{tabular}

monopoly" companies, as well as privatised generating and sales companies appeared.

The holding company Russian Aluminum, which is managed by Oleg Deripaska and Roman Abramovich, also deserves attention. The joint holding has raised over $\$ 49$ million from Sberbank to finance investment programs at the Sayanogorsk Aluminum Smelter. ${ }^{24}$

Volga-Dnepr Airlines, actively participating in numerous hot spots around the globe, also received $\$ 10$ million for 4.5 years. ${ }^{25}$

Privatised in 1994, Siberia, currently S 7, received \$ 15.8 million $^{26}$ from the Novosibirsk bank of Sberbank of Russia to finance the costs of the program to expand and modernise its air fleet.

North Oil CJSC and Tyumen Oil Company received $\$ 2.5$ million ${ }^{27}$ and $\$ 300$ million, ${ }^{28}$ respec-

\footnotetext{
${ }^{24}$ Sberbank of Russia and Russian Aluminum OJSC signed a loan agreement. Available at URL: https://www.sberbank.ru/ $\mathrm{ru} /$ press_center/all/article?newsID=2504-1-1 \&blockID=1303 \&regionID=77 \&lang=ru \&type=NEWS. (Accessed 28.11.2020).

${ }^{25}$ Sberbank gave money for Ruslan to Volga-Dnepr Airlines. Available at https://lenta.ru/news/2000/08/14/ruslan. (Accessed 28.11.2020).

${ }^{26}$ Sberbank of Russia and Siberia Airlines signed a loan agreement. Available at https://www.sberbank.ru/ru/press center/ all/article?newsID=2350-1-1 \&blockID=1303\&regionID =77 \& lang=ru\&type=NEWS. (Accessed 29.11.2020).

${ }^{27}$ CJSC "Severnaya Neft" received a loan of the Savings Bank of Russia in the amount of \$ 2.5 million. Available at https:// komiinform.ru/news/5611. (Accessed 28.11.2020).

${ }^{28}$ Sberbank of Russia and OJSC Tyumen Oil Company signed a General Agreement on Cooperation. Available at https:/www. sberbank.ru/ru/press_center/all/article?newsID $=2362-1-1 \&$ bl
} 
Table 6

The dollar/ruble exchange rate in 2020, in 1991 (liquidation of Sberbank) and at the time of opening deposits, the calculations for which are given in the examples

\begin{tabular}{cccccc}
\hline Year & 1980 & 1990 & Official Exchange Rate & $\begin{array}{r}\text { Black Market } \\
\text { Exchange Rate }\end{array}$ & 2020 \\
\cline { 4 - 5 } $\begin{array}{c}\text { Rate of rubles per } \\
\text { dollar }\end{array}$ & 0.6395 & 0.6072 & 0.5605 & 30.33 & 75.85 \\
\hline
\end{tabular}

Source: Website of the Central Bank: Currency rates for the period up to 01.07.1992. Available at https://www.cbr.ru/currency_ base/OldVal. (Accessed 27.11.2020).

Table 7

Calculation of the compensation of Example 2

\begin{tabular}{cc}
\hline Deposit on June 1991, rubles & 3000 \\
\hline Deposit on June 1991, USD & 5352,363961 \\
Age coefficient & 2 \\
Deposit closing date coefficient & 0.8 \\
Compensation in rubles & 4800 \\
Compensation in USD & 64 \\
\hline
\end{tabular}

Table 9

Calculation of the compensation of Example 2
Table 8

Calculation of the compensation of Example 2

\begin{tabular}{cc}
\hline Deposit on June 1991, rubles & 6500 \\
\hline Deposit on June 1991, USD & 11596,78858 \\
Age coefficient & 3 \\
Deposit closing date coefficient & 1 \\
Compensation in rubles & 17500 \\
Compensation in USD* & 233,3333333 \\
\hline
\end{tabular}

*distraction of 2000 rubles received in 2009

\begin{tabular}{|c|c|c|}
\hline Deposit on June 1991, rubles & 6200 & 2200 \\
\hline Deposit on June 1991, USD & 11061,55219 & 3925,066905 \\
\hline Age coefficient & 3 & 3 \\
\hline Deposit closing date coefficient & 0,8 & 0,8 \\
\hline Compensation in rubles & 14880 & 5280 \\
\hline Compensation in USD & 198,4 & 70,4 \\
\hline The whole sum of compensation in rubles & \multicolumn{2}{|c|}{20160} \\
\hline The whole sum of compensation in USD & \multicolumn{2}{|c|}{268,8} \\
\hline
\end{tabular}

tively, to finance projects for the development of large oil and gas fields, for the reconstruction, modernisation, and capacity expansion of oil refineries.

VimpelCom JSC received about $\$ 70$ million $^{29}$ for the implementation of a regional project to create a large-scale cellular network.

ockID=1303 \&regionID=77 \&lang=ru \&type=NEWS. (Accessed 28.11.2020).

${ }^{29}$ Sberbank of Russia opened a credit line for OJSC "Vimpelcom-Region". Available at https://www.sberbank.ru/ru/press center/all/article?newsID=2642-1-1 \&blockID=1303\&regionI $\mathrm{D}=77$ \&lang=ru \&type $=$ NEWS. (Accessed 28.11.2020).
Overall, in 2000 Sberbank actively allocated funds, focusing not only on the real sector of the economy but on everything that came to hand. By lending money to a variety of companies directly or indirectly involved in the domestic and foreign policy of the newly formed country, the question about the true purpose of the investments made remains ambiguous.

2001-2007 period is also considered to be a milestone in the history and formation of Sberbank. On 1 January 2001, there had been a reorganisation, as a result of which 79 regional banks of Sberbank of Russia were merged into 17 territorial ones. 
In 2002, Sberbank issued the first VISA Aeroflot cards. This event may be connected with the first Russian president's "Family". Particularly with the husband of Yeltsin's daughter - Valeriy Okulov, who used to be a president of Aeroflot. Anyway, the project's initial purpose aimed at facilitation of domestic and international flights was economically successful (not taking into consideration common people)

In 2006 Sberbank implemented its policy of expansion on international markets and opened a representative office in Kazakhstan, and in 2007 in Ukraine. On 28 November 2007 German Gref was approved as a Chairman of the Management Board of Sberbank of Russia. Interestingly, Anatoly Sobchak was the scientific supervisor of the future head of the bank, and later on Gref acquainted with Vladimir Putin. Gref took place shortly before the 2008 elections, where Dmitry Medvedev was elected to the post of President of the Russian Federation.

The Supervisory Board of Sberbank unanimously approved the strategy "Development of Sberbank until 2014" on 21 October 2008. The Production System of Sberbank was developed, based on the technology of thoughtful and economical production. The Sberbank Online service was launched, thanks to which the bank's clients in the Moscow region were able to conduct banking transactions on the Internet any time they wanted. A new project "Credit Factory" was introduced, the key feature of which was the automation of the decision-making process for issuing a loan. In 2008 , Sberbank received the status of a strategic partner of the World Economic Forum in Davos (Switzerland), which may indicate the desire of President Medvedev to strengthen his status in the international arena, and the Russian banking and financial sector in the international business community.

2009 became the starting point for the largescale deployment and implementation of the Sberbank Development Strategy. The task of the bank was to help people alleviate the problems caused by the global financial crisis and stabilise their financial situation. "We have cancelled lending volumes in our business plan, putting forward reliability and guarantees of security for the repayment of loans issued by us as a priority", said German Gref. According to the reports of Sberbank, the volume of payments to the members of the bank's board for 2007 amounted to 892.1 million rubles, and the volume of payments accrued for 2008 was 933.5 million rubles. Apart from this superior decision, Sberbank cut interest rates and created a special unit to work with citizens, especially older people, whose monthly income did not exceed 25 thousand rubles.

In October 2009, Sberbank began servicing Master Card Platinum, VISA Platinum and VISA Infinite cards. Sberbank offered its clients a new type of brokerage services in the stock market Internet trading using the Focus IV Online remote access system. Sberbank's positions on the Russian and international markets continued to strengthen: Sberbank entered the top 20 largest banks by market capitalisation. In December 2009, Sberbank Group acquired a controlling stake in BPS-Bank OJSC. A representative office of Sberbank of Russia was opened in Germany, in Frankfurt am Main, an unofficial centre for commercial transactions in Europe. The bank's desire to establish a 'decorative' branch in the European market after the recent crisis is rather controversial. Besides, the bank's charitable activities started to develop actively, and Sberbank's Social Card was issued. A unique and innovative "Office of the Future Sberbank" was opened in Moscow.

On 17 September 2012, the first stage of Sberbank's privatisation was initiated by Bank of Russia, who sold 7.58 per cent stake of Sberbank from its portfolio and earned 5.2 billion rubles. What was the objective of this deal? In general, privatisation may have three obvious goals: fiscal (to increase budget revenues), ideological (reducing the impact of the state on the economy) and, pragmatic (improve the enterprise's management, attract new investors).What do we see in the privatisation of Sberbank? An ideological goal is not pursued - in the hands of the Central Bank, in full compliance with the law on the Central Bank, 50 per cent +1 share, that is, a controlling stake. Actually, no denationalisation of Sberbank took place - it remained the same state bank as it was before privatisation. The role of the state in the banking sector is not decreasing. The fiscal target is a controversial issue since only 75 per cent of this money will be transferred to the federal budget following the budget law the CBR transfers 75 per cent of its profits to the budget. 


\section{3}

In the Sberbank's 2013 annual report, a separate chapter was devoted to investment in human capital. It was reflected in the bank's employees: an opportunity for advanced training was provided not only for heads of departments and key specialists but for employees of mass specialities too. ${ }^{30}$ Such programs are significant since they contribute to an increase in the HDI (human development index), which includes the measurement of human potential, for which constant training of already employed people is important.

In 2013, the Ukrainian question emerged. Since this year, branches of the subsidiary bank of Sberbank in Ukraine have become the objects of attention of the activists of the campaign "Don't buy anything Russian!” The activists urged not to receive services from Sberbank, pointing to the Russian origin of the bank's owners. In November a massive months-long protest action began in the centre of Kyiv - Euromaidan. In December demonstrations took place in Crimea.

\section{4}

In 2014 Russia annexed part of the Crimea peninsula, and since that time its status has remained a matter of dispute. According to the official results of the referendum on the status of Crimea, held on 16 March 2014, the majority of Crimea population voted in favour of the annexation of Crimea to Russia. ${ }^{31}$ But Ukraine refuses to recognise the affiliation of Crimea to Russia and considers the peninsula Ukrainian territory, which Russia has temporarily occupied. The majority of the United Nations member states have the same position according to the UN General Assembly Resolution 68/262. ${ }^{32}$ The fact is that according to the legislation of Ukraine, ${ }^{33}$ the issue of changing the borders should be resolved

\footnotetext{
${ }^{30} 2013$ Annual Report of Sberbank of Russia. Available at https://www.sberbank.com/common/img/uploaded/files/pdf/yrep/ annual_report_ru_2013.pdf. (Accessed 27.11.2020).

${ }^{31}$ Referendum in Crimea on the status of autonomy 2014. Available at https://ria.ru/20150316/1052210041.html. (Accessed 27.11.2020).

${ }^{32}$ UN General Assembly Resolution "Territorial integrity of Ukraine” from 27 March 2014 A/RES/68/262.

${ }^{33}$ Constitutional Court declared unconstitutional the decision of the Verkhovna Rada of Crimea on independence. Available at http://www.unian.net/politics/899002-ks-priznal-nekonstitutsionnyim-postanovlenie-vr-kryima-o-nezavisimosti.html. (Accessed 27.11.2020).
}

at the national level. At the same time, the referendum was held only on the Crimea peninsula. Then a wave of outcries against Russian banks, including against Sberbank, swept across Ukraine. ${ }^{34}$ Later Sberbank stopped dealing in Crimea, and some of the branches were transferred to the RNKB. ${ }^{35}$

It is this historical event that shows the duality of Sberbank's position. It is the largest bank in Russia, aimed at becoming a worthy player in the global banking league. But it is considered both in Russia and in the world to be state-owned and is perceived as an instrument of the Russian state; therefore, since 1 August 2014, sanctions were imposed on Sberbank. ${ }^{36}$ Financial institutions were being restricted from entering the European capital market: banks and their subsidiaries (with a share of $50 \%$ or more) were not able to attract new debt and equity capital to the EU for more than 90 days. Japan, USA, Canada also imposed sanctions against Sberbank. ${ }^{37}$ Since December 2015, the United States has also imposed sanctions against affiliated banks in Belarus, Ukraine, Kazakhstan, Switzerland, as well as Sberbank Capital, Sberbank Europe, Sberbank Finance, Sberbank Insurance, Sberbank investments and Sberbank Leasing". 38

Sberbank of Russia for the first time in October 2014 applied to the Court of Justice of the European Union with a statement of claim to annul the decision of the EU Council on the application of sanctions against the bank concerning Russia.

\footnotetext{
${ }^{34}$ Miners and metallurgists of Kryvbas for a civilized refusal to cooperate with Russian banks. Confederation of Free Trade Unions of Ukraine. Available at https://kvpu.org.ua/uk/ news/4/3275/gornyaki-i-metallurgi-krivbassa-za-civilizovannyjj-otkaz-ot-sotrudnichestva-s-rossijjskimi-bankami. (Accessed 27.11.2020).

${ }^{35}$ Sberbank of Russia in Ukraine stops the work of its branches in Crimea. Available at https://ria.ru/20140507/1006811078. html. (Accessed 27.11.2020). Sberbank transferred part of its branches in Crimea to RNKB. Available at https://ria. $\mathrm{ru} / 20140411 / 1003554779 . h t m l$. (Accessed 27.11.2020).

${ }^{36}$ Sberbank fell under EU sanctions. Available at https://www. vedomosti.ru/finance/articles/2014/07/31/sberbank-popalpod-sankcii-es. (Accessed 27.11.2020).

${ }^{37}$ Canadian Foreign Ministry announced the expansion of the list of sanctions against Russia. Available at https://ria. $\mathrm{ru} / 20140916 / 1024394129 . h t m l$. (Accessed 27.11.2020).

${ }^{38}$ US Ministry of Finance expanded the sanctions list in connection with the crisis in Ukraine. Available at https://ria. $\mathrm{ru} / 20151222 / 1346973194 . h t m l$. (Accessed 27.11.2020). The United States added three Crimean wineries to the sanctions list. Available at https://ria.ru/20151222/1346989108.html. (Accessed 27.11.2020).
} 
The sanctions have not been lifted and are still in effect.

\section{5}

In August 2015, the full name of the bank was changed to Public Joint Stock Company Sberbank of Russia (PJSC Sberbank). It allowed Sberbank to alter its organisational and legal form and structure. The point is that in a public jointstock company, the number of shares owned by one shareholder and the maximum number of votes given to one shareholder can be unlimited. It is stated in article 97 of the Civil Code of the Russian Federation. As the result, it is possible for one person or one organisation to become the only owner of Sberbank.

\section{6}

2016 was a very successful year for Sberbank. According to news sources, in 2016, Sberbank became the most expensive Russian brand - it came out on top in terms of capitalisation. ${ }^{39}$ The bank's net profit increased more than twice times - it amounted to 541.9 billion rubles in 2016 (in comparison to 222.9 billion rubles in 2015). ${ }^{40}$ Interfax adds that all foreign-affiliated companies of Sberbank, except for the Ukrainian one, were profitable. The total loss of Sberbank from business in Ukraine amounted to 7 billion rubles. ${ }^{41}$

\section{7}

2017 was the year of summing up the "results" of the ten-year management of Sberbank by German Gref. Despite several controversial points during these ten years, they became insignificant as soon as in 2017, Sberbank's net profit increased even more than in 2016 and amounted to 748.7 billion rubles.

In 2017 Sberbank launched its project based on the Tele2 network, a virtual mobile operator "Pogovorim" and a service for searching and buying real estate "DomClick".

\footnotetext{
${ }^{39}$ Sberbank became the most expensive company in Russia for the first time. Available at https://www.rbc.ru/finances/28/11/2 016/583c452c9a7947507a82ec9a. (Accessed 27.11.2020).

402016 Annual Report of Sberbank of Russia. Available at https://www.sberbank.com/common/img/uploaded/files/pdf/ stockholders/2017/godovoy_otchet_banka_za_2016_god.pdf. (Accessed 27.11.2020).

${ }^{41}$ Sberbank in 2016 increased its net profit by two and a half times. Available at https://www.interfax.ru/business/551963. (Accessed 27.11.2020).
}

Also, 2017 was the beginning of permanent M\&A programs: Sberbank concluded deals and owns 25 per cent of the "VisionLabs" face recognition system, the "Beru" marketplace in an equal share with Yandex - the deal was completely closed in 2018. "Beru" is called the Russian Amazon - it is an online platform for different sellers. Sberbank bought out $45 \%$ of Yandex.Market shares for 30 billion rubles. ${ }^{42}$

\section{8}

In 2018 the issue of privatising Sberbank was actively discussed. Remarkably is that German Gref also announced his intention to privatise Sberbank in 2015, when he gave an interview to the German newspaper "Handelsblatt", ${ }^{43}$ as well as he mentioned Sberbank's privatisation in 2010 at the forum in Davos. ${ }^{44}$ Throughout this time, the Ministry of Finance (represented by Alexei Kudrin in 2010) and the chairman of the Central Bank (represented by Elvira Nabiullina in 2015) have been opposed to privatisation. Sberbank was not privatised and still is not.

Some deals for the acquisition of shares in several companies and projects continued. Since 2018 Sberbank owns the "SberCloud "cloud storage platform for 60 per cent and a unified digital platform for the "Foodplex" restaurant market by 35 per cent. ${ }^{45}$ Sberbank wholly owns "Intercomp" outsourcing of business services. ${ }^{46}$

\section{9}

In July 2019, Sberbank announced that it had sold DenizBank to Dubai's Emirates NBD

${ }^{42}$ Sberbank closed a deal with Yandex.Market. Available at https://www.vedomosti.ru/business/articles/2018/04/27/768146sberbank-yandeksmarketom. (Accessed 27.11.2020).

${ }^{43}$ Sberbank boss calls for full privatization. Available at https://www.handelsblatt.com/finanzen/banken-versicherungen/ herman-gref-sberbank-chef-fordert-vollstaendige-privatisierung/12625208.html. (Accessed 27.11.2020).

${ }^{44}$ Gref proposed to privatize Sberbank. Available at https:// www.infox.ru/news/164/39251-gref-predlozil-privatizirovatsberbank. (Accessed 27.11.2020).

${ }^{45}$ Sberbank took off into the clouds. Available at https://www. comnews.ru/content/112517/2018-04-03/sberbank-vzletelv-oblaka. (Accessed 27.11.2020). Sberbank and Rambler have closed a deal to create a platform for the Foodplex restaurant market. Available at https://rb.ru/news/sberbank-ramblerfoodplex. (Accessed 27.11.2020).

${ }^{46}$ Sberbank enters the business process outsourcing market. Available at https://www.sberbank.ru/ru/press_center/all/ article?newsID=e12c329e-69a0-4602-96d7-111e418a2904\& blockID=1303 \&regionID=77 \&lang=ru \&type=NEWS. (Accessed 27.11.2020). 
(On 8 June 2012, a final agreement was signed on the acquisition of 99.85 per cent of DenizBank shares by Sberbank for 6.469 billion). ${ }^{47}$ The total cash flow of Sberbank from the transaction amounted to approximately $\$ 5$ billion. The total volume of investments made by the credit institution for the entire period of DenizBank's ownership was estimated at 148 billion rubles. ${ }^{48}$ According to Gref, due to the sanctions regime, Sberbank cannot receive dividends, cannot provide financing to a Turkish bank and, consequently, cannot attract money. ${ }^{49}$

The issue of Sberbank's privatisation in 2019 has become even more acute. There was a data leak from Sberbank in October. Sberbank had had 96.2 million active private clients and 2.6 million active corporate clients in $2019 . .^{50}$ Information on the number of affected customers varies depending on different sources: Sberbank announced the number of 200 customers in its press release, the Interfax information resource adds that Sberbank confirmed the data leak of 5000 people, while the "Kommersant" newspaper even writes about 60 million bank cards that appeared on the black market. ${ }^{51}$ After this

incident, the privatisation of the bank began to seem dangerous: data can leak abroad, which could become a threat to the security of all of Russia.

Sber 2020 Conference: Highlights and the Main Changes ${ }^{52}$

\footnotetext{
${ }^{47}$ Sberbank of Russia OJSC announces the acquisition of 99.85\% of DenizBank shares. Available at https://www.sberbank.ru/ru/press_center/all/article?newsID $=11018524-1-1 \& \mathrm{bl}$ ockID=1303 \&regionID=77 \&lang=ru \&type=NEWS. (Accessed 27.11.2020).

${ }^{48}$ Sberbank sold its Turkish subsidiary bank for $\$ 5$ billion due to sanctions. Available at https://www.rbc.ru/finances/31/07/2019/5d41 85139a79470944f1b17f. (Accessed 27.11.2020).

${ }^{49}$ Gref explained the decision to sell Denizbank by the negative impact of EU sanctions. Available at https://tass.ru/ekonomika/5222747. (Accessed 27.11.2020).

${ }^{50} 2018$ Annual Report of Sberbank of Russia. Available at https://www.sberbank.com/common/img/uploaded/redirected/ com/gosa2019/docs/sberbank-annual_report_2018_rus.pdf. (Accessed 27.11.2020).

${ }^{51}$ Sberbank informs about the activities in connection with a possible information leak. Available at https://www.sberbank. $\mathrm{ru} / \mathrm{ru} /$ press_center/all/article?newsID=e71 ce593-484c-43ab-9 0ad-7c4681313b40\&blockID=1303 \& regionID=77 \&lang=ru \&t ype=NEWS. (Accessed 27.11.2020). Sberbank announced 5,000 victims of data breaches. Available at https:/www.interfax.ru/ business/679460// (Accessed 27.11.2020). Sberbank clients hit the black market. Available at https://www.kommersant.ru/ doc/4111863?from=main_1. (Accessed 27.11.2020).

${ }^{52}$ Sber's digital ecosystem. Available at Экосистема СберБанк (sberbank.com). (Accessed 27.11.2020).
}

\section{Service in offices and ATMs}

The bank's branches have adopted special zones for children with games, cartoons and consoles. Systems for recognising customers by biometric data will appear, whereas "bulletproof glass" and other barriers will disappear. Moreover, the service offices will be equipped with checkpoints where it will be possible to send and receive parcels.

The SberPay payment system was presented with the ability to choose a card for payment, which can be connected in the Sberbank Online application. Sberbank's subsidiary Bi. Zone will be responsible for transaction security. In the new generation of ATMs, transactions would be carried out without a card using biometrics with the help of commands by voice.

\section{Transport services}

Citymobil, which is part of the joint venture of Sberbank and Mail.ru Group, implemented a new function connected with the transport change. A taxi can take a client to the parking of a scooter, the rental of which has already been included in the price of the trip. It has been made in order to cut the distance through traffic jams while using the option, and the passenger can get a discount.

In the future, the service will add bike rentals and build routes in combination with public transport to speed up the trip thanks to the integration with the 2GIS map service, which will allow a person to plan a route and see reviews about the enterprise.

SberLogistika promises to launch delivery of goods within 15 minutes in Moscow and St. Petersburg this year and to expand its service throughout the territory of the Russian Federation.

\section{Education}

Sberbank launched the personalised interactive educational system Sberklass in 65 Russian regions, which will help students to review and reinforce the material they have learned and to facilitate the process of doing their homework as well as carrying out team projects.

\section{Business services}

A tool for evaluating business ideas has appeared, in which an entrepreneur can calculate a business development model for five years 
ahead and find out how long it will take to pay off their investments. The Sberbank Business Online application has implemented a service that replaces a full-time accountant - "My Accounting Outsourcing”. Also, business clients have access to a partner service of legal support of the company. Employee search service Rabota. $\mathrm{ru}$, launched jointly with Mail.ru Group, using the auto-selection function will help an entrepreneur to find a full-time employee.

The Sbersovetnik will help to figure out the average salary in the market for a particular vacancy and determine the level of staff turnover. To select partners, entrepreneurs will have access to the bank's counterparty verification service, which analyses information from open sources and identifies the following risks. It is now possible to rent an online cashier with an acquiring terminal in the application from Evotor partners who offer to create a reliable website for business on Sber Cloud.

\section{Food-tech industry}

Now while booking a restaurant through Delivery Club's application the app's recommendation system will help clients to choose a suitable place based on previous orders, and the service's algorithms will enable to collect a grocery basket in the store based on the past orders.

\section{Entertainment}

The Sberzvuk music service was also presented during the conference. In addition to music and podcasts, "Stories" become available in the application, from which it is possible to learn about the latest events in the industry.

Sber's ecosystem also included an online cinema - Okko. Its content can be watched together with friends, with an ability to discuss the plot in the chat, and the service will also allow ordering some popcorn.

\section{Devices and personal assistant}

At Sberkonf a family of voice assistants "Salyut" was announced, which consists of three assistants: Sber that advises on financial services, Athena, which composes an assignment planner, reads the news and performs tasks, and Joy, who can order delivery in charge of leisure and entertainment, select a movie and a playlist.

Sberbank also released its gadgets with its own TV set. Sberbox TV is a set-top box with
185 TV channels, games and a voice assistant, through which it is possible to choose the image of the hero of your favourite movie while watching it or order popcorn and cola using the Scooter. Sberbox comes with special minijoysticks that can be attached to a smartphone, turning it into a gamepad to control the game on the TV screen.

Another gadget from the bank is Sberportal, which is a tablet with a smart camera that always focuses on the user. The camera allows a person to control the device by reading biometrics, and Salyut virtual assistants can make an appointment with a doctor or hairdresser.

\section{App Store}

Sberbank has created an alternative to AppStore and Google Play SmartMarket, where special applications will appear, supplemented with communication skills by text, voice, touching the screen and gestures.

It is possible to develop applications for the SmartMarket store even without writing code according to a special template. A business can create not only applications but also skills. For example, $\mathrm{S} 7$ made a skill for ordering tickets while watching a movie on Okko.

\section{Subscription}

The subscription to the services of the SberPrime ecosystem includes the Okko online cinema, Sberzvuk, SberMarket, SberDisk, SberMobile, Delivery Club, Citymobil. The subscription costs 199 rubles per month and gives discounts on services and the opportunity to use some of them for free.

\section{Covert Operation "Sberbank”: Transfer of Control Stake from Central Bank to the Ministry of Finance ${ }^{53}$}

The Bank of Russia used to combine the roles of a shareholder, regulator, and supervisory authority for Sberbank, which inevitably lead to an inevitable conflict of interest. The sale of shares must have helped to isolate the regulator from all participants in the financial market and thus resolve this contradiction.

53 The Central Bank sold Sberbank to the government. Why? And how much was the deal?, TASS [Electronic resource].URL: https://tass.ru/ekonomika/7737581// (Accessed 27.11.2020) 
What was the true purpose behind the deal? Was the deal's rationale solely a political or an economic issue ${ }^{54}$

The motives of the Central Bank are explained simply and trivially: it needs to cover losses of 0.9 trillion rubles throughout the two years from 2017-2018. Although the fact that the bank that prints money incurs financial losses is quite impressive, the willingness to improve its current state at the expense of the federal budget leads to somewhat ambiguous conclusions.

The Central Bank may have another objective, which is connected with the spending money from the National Welfare Fund (NWF. According to the Budget Code, the Ministry of Finance has the right to invest at the expense of the NWF over 7 per cent of GDP. This year they appeared in the amount of more than a trillion rubles. Obviously, the queue of the richest stateowned companies and people in the country like Rosneft, Rosatom, Leonid Mikhelson, Arkady Rotenberg, Vladimir Potanin consequently appeared. Having taken almost 3 trillion rubles from the NWF, the Central Bank again "drives" NWF below the 7 per cent level and leave the Russian billionaires with no money in such a turbulent period.

Also, when transferring a package from one government agency to another, according to the law, selling a large block of shares implied that the seller (in this case the Central Bank) is obliged to make an offer to minority shareholders at the same price. And the Ministry of Finance confirmed that such a proposal is planned to be made. And suppose minority shareholders take at least 2 shares at this price (spending only a little more than 500 rubles). In that case, the Russian state will immediately erode the controlling stake, which will lead to the privatisation of Sberbank. It is worth noting that even now, 45.04 per cent of Sberbank's shares are held by non-resident legal entities. If they buy a little more, then Sberbank becomes not just a non-state, but formally a foreign bank. It may be suggested that these non-resident legal entities are not foreigners at all, but top Russian officials who, on the

\footnotetext{
${ }^{54}$ Covert Operation "Sberbank", Riddle [Electronic resource].URL: https://www.ridl.io/en/covert-operation-sberbank // (Accessed 27.11.2020).
}

eve of the transit of power in 2024, decided to buy Sberbank.

\section{Conclusion}

During the process of examining this topic, the history of the development of the Savings Bank of Russia had been studied, and its main social and economic functions had been indicated. The research group managed to describe the current state of Sber, its role in the banking system and priority directions of its further development.

Founded in 1841 by the Decree of the Russian Emperor Sberbank, as an enterprise with only two small institutions with 20 employees in St. Petersburg and Moscow grew into a network of institutions, working throughout the country and accumulating funds for the implementation of central government projects. During the Soviet era, it was transformed into a system of State Labor Savings Banks. It, later on, came into life as a modern universal bank, a large international group and an ecosystem, which is known in more than 20 countries around the world.

Nowadays this financial institution has significantly expanded its network of influence, partially taking over the functions, that were considered the monopoly of a National State (e.g. playing a role in domestic and foreign policy) and even state debts to the population. As a leader of the domestic banking system, Sber actively participates in the formation of economic policy influencing macroeconomic processes in the country, sometimes serving as the wallet (ill-wishers even say as money laundry reminding cases like TroikaDialog or similar) of the Russian elites. Via an extensive branch network, it tries to meet the needs of various customer groups and provide a wide range of banking services, making it the most popular bank.

The rebranding strategy implemented in 2020 was a revolutionary act in the history of the bank. Introduced innovations tend to simplify peoples' lives. Still, they simultaneously may reduce privacy since the authority to store fingerprints and face metrics may be vulnerable to federal services and the government's intervention. Overall, the proposed actions will lead to a qualitatively new level of service, maintaining the position of a large competitive bank in Eastern Europe. To achieve these goals, the bank must introduce a wide range of new banking products based on new technolo- 
gies and make more efficient use of the existing competitive advantages. A significant resource base and capital will allow it to provide extensive and long-term loans and investments for raising funds in international financial markets. Improving the quality of Sberbank's economic activities and its further functioning is connected with the overall Russian economic and political system. Thus, soon it is necessary to continue the process of bank's privatisation, reach a brand-new level of flexibility, and react quickly to changing market conditions.

\section{References}

2013 Annual Report of Sberbank of Russia. Retrieved from https://www.sberbank.com/common/img/uploaded/files/ pdf/yrep/annual_report_ru_2013.pdf. (Accessed 27.11.2020).

2016 Annual Report of Sberbank of Russia. Retrieved from https://www.sberbank.com/common/img/uploaded/files/ pdf/stockholders/2017/godovoy_otchet_banka_za_2016_god.pdf. (Accessed 27.11.2020).

2018 Annual Report of Sberbank of Russia. Retrieved from https://www.sberbank.com/common/img/uploaded/redirected/com/gosa2019/docs/sberbank-annual_report_2018_rus.pdf. (Accessed 27.11.2020).

Bill No. 1027743-7 On the federal budget for 2021 and for the planning period 2022, 2023.

Canadian Foreign Ministry announced the expansion of the list of sanctions against Russia, RIA Novosti. Retrieved from https://ria.ru/20140916/1024394129.html. (Accessed 27.11.2020).

CJSC “Severnaya Neft” received a loan of the Savings Bank of Russia in the amount of \$ 2.5 million. Retrieved from https://komiinform.ru/news/5611. (Accessed 28.11.2020).

Compensation for deposits, Sberbank website. Retrieved from https://www.sberbank.ru/ru/person/contributions/ compensation. (Accessed 27.11.2020).

Constitutional Court declared unconstitutional the decision of the Verkhovna Rada of Crimea on independence, UNIAN. Retrieved from http://www.unian.net/politics/899002-ks-priznal-nekonstitutsionnyim-postanovlenie-vr-kryima-o-nezavisimosti.html. (Accessed 27.11.2020).

Council of Ministers of the RSFSR Resolution of 20 March 1991 No. 162 On the reform of retail prices and social protection of the population of the RSFSR.

Covert Operation “Sberbank”, Riddle. Retrieved from https://www.ridl.io/en/covert-operation-sberbank. (Accessed 27.11.2020).

Decree dated 22 January 1991 No. 20 On termination of acceptance for payment of banknotes State Bank of the USSR in denominations of 50 and 100 rubles sample 1961 and the procedure for their exchange and restrictions on issuance cash from deposits of citizens.

Decree of the President of the USSR from 22.03.1991, No. UP-1708 On compensation to the population for losses from the depreciation of savings in connection with a one-time increase in retail prices.

Decree of the President of the USSR of 22 January 1991 No. UP-1329 On the termination of the acceptance for payment of banknotes of the State Bank of the USSR in denominations of 50 and 100 rubles of the 1961 model and the restriction of the issuance of cash from the deposits of citizens.

Federal Law On Banks and Banking Activities dated 02.12.1990 No. 395-1.

Federal Law of 29.11.2018 No. 459-FZ (amended on 02.12.2019) On the federal budget for 2019 and for the planning period of 2020 and 2021.

Gref explained the decision to sell Denizbank by the negative impact of EU sanctions, TASS. Retrieved from https://tass.ru/ekonomika/5222747. (Accessed 27.11.2020).

Gref proposed to privatise Sberbank, Infox. Retrieved from https://www.infox.ru/news/164/39251-gref-predlozilprivatizirovat-sberbank. (Accessed 27.11.2020).

History of Sberbank. Retrieved from https://www.sberbank.com/ru/about/history. (Accessed 26.11.2020).

Kashin Y.I. (1979). The savings rate in the USSR. Moscow: Finances.

Miners and metallurgists of Kryvbas for a civilised refusal to cooperate with Russian banks. Confederation of Free Trade Unions of Ukraine. Retrieved from https://kvpu.org.ua/uk/news/4/3275/gornyaki-i-metallurgi-krivbassaza-civilizovannyji-otkaz-ot-sotrudnichestva-s-rossijjskimi-bankami. (Accessed 27.11.2020).

Mortality of the population: trends, methods of study, forecasts: Collection of articles. (2007). Denisenko M.B., Ed. Bakhmetova G. Sh. Moscow: MAKS Press. pp. 256-271.

Pushkareva I.M., Stepanov A.S. The «Golden» ruble in the Russian monetary system in 1897-1917. 
Referendum in Crimea on the status of autonomy 2014, RIA Novosti. Retrieved from https://ria.ru/20150316/ 1052210041.html. (Accessed 27.11.2020).

Resolution of Supreme Council of the USSR "On the implementation of the law of the USSR "On the state bank of the USSR" and the law of the USSR “on banks and banking activities” 11 December 1990 № 1830-1.

Sberbank and Rambler have closed a deal to create a platform for the Foodplex restaurant market, RusBase. Retrieved from https://rb.ru/news/sberbank-rambler-foodplex. (Accessed 27.11.2020).

Sberbank announced 5,000 victims of data breaches, Interfax. Retrieved from https://www.interfax.ru/business/679460. (Accessed 27.11.2020).

Sberbank became the most expensive company in Russia for the first time, RBC. Retrieved from https://www.rbc.ru/ finances/28/11/2016/583c452c9a7947507a82ec9a. (Accessed 27.11.2020).

Sberbank boss calls for full privatisation, Handelsbatt. Retrieved from https://www.handelsblatt.com/finanzen/banken-versicherungen/herman-gref-sberbank-chef-fordert-vollstaendige-privatisierung/12625208.html. (Accessed 27.11.2020).

Sberbank clients hit the black market, Kommersant. Retrieved from https://www.kommersant.ru/ doc/4111863?from=main_1. (Accessed 27.11.2020).

Sberbank closed a deal with Yandex.Market, Vedomosti. Retrieved from https://www.vedomosti.ru/business/ articles/2018/04/27/768146-sberbank-yandeksmarketom. (Accessed 27.11.2020).

Sberbank enters the business process outsourcing market, Sberbank press release. Retrieved from https://www. sberbank.ru/ru/press_center/all/article?newsID=e12c329e-69a0-4602-96d7-111e418a2904\&blockID=1303\&r egionID=77 \&lang=ru \&type=NEWS. (Accessed 27.11.2020).

Sberbank fell under EU sanctions, Vedomosti. Retrieved from https://www.vedomosti.ru/finance/articles/2014/07/31/ sberbank-popal-pod-sankcii-es. (Accessed 27.11.2020).

Sberbank gave money for Ruslan to Volga-Dnepr Airlines, Lenta. Retrieved from https://lenta.ru/news/2000/08/14/ ruslan. (Accessed 28.11.2020).

Sberbank in 2016 increased its net profit by two and a half times, Interfax. Retrieved from https://www.interfax.ru/ business/551963. (Accessed 27.11.2020).

Sberbank informs about the activities in connection with a possible information leak, Sberbank press release. Retrieved from https://www.sberbank.ru/ru/press_center/all/article?newsID=e71ce593-484c-43ab-90ad-7c468131 3b40\&blockID=1303\&regionID=77 \&lang=ru\&type=NEWS. (Accessed 27.11.2020).

Sberbank of Russia and OJSC Tyumen Oil Company signed a General Agreement on Cooperation, Sberbank press release. Retrieved from https://www.sberbank.ru/ru/press_center/all/article?newsID=2362-1-1\&blockID=1303 \&regionID=77 \&lang=ru\&type=NEWS. (Accessed 28.11.2020)

Sberbank of Russia and Russian Aluminum OJSC signed a loan agreement, Sberbank press release. Retrieved from https://www.sberbank.ru/ru/press_center/all/article?newsID=2504-1-1\&blockID=1303\&regionID=77\&lang=ru \&type=NEWS. (Accessed 28.11.2020).

Sberbank of Russia and Siberia Airlines signed a loan agreement, Sberbank press release. Retrieved from https://www.sberbank.ru/ru/press_center/all/article?newsID=2350-1-1\&blockID=1303\&regionID=77 \&lang=ru\&t ype=NEWS. (Accessed 29.11.2020).

Sberbank of Russia in Ukraine stops the work of its branches in Crimea, RIA Novosti. Retrieved from https://ria. $\mathrm{ru} / 20140507 / 1006811078 . \mathrm{html}$. (Accessed 27.11.2020).

Sberbank of Russia OJSC announces the acquisition of $99.85 \%$ of DenizBank shares, Sberbank press release. Retrieved from https://www.sberbank.ru/ru/press_center/all/article?newsID=11018524-1-1\&blockID=1303\&regi onID=77 \&lang=ru\&type=NEWS. (Accessed 27.11.2020).

Sberbank of Russia opened a credit line for OJSC “Vimpelcom-Region”, Sberbank press release. Retrieved from https://www.sberbank.ru/ru/press_center/all/article?newsID=2642-1-1\&blockID=1303\&regionID=77 \&lang=r u\&type=NEWS. (Accessed 28.11.2020).

Sberbank opened a loan to RAO “UES of Russia”, Kommersant. Retrieved from https:/www.kommersant.ru/ doc/152456. (Accessed 28.11.2020).

Sberbank sold its Turkish subsidiary bank for $\$ 5$ billion due to sanctions, $R B C$. Retrieved from https://www.rbc.ru/ finances/31/07/2019/5d4185139a79470944f1b17f. (Accessed 27.11.2020).

Sberbank took off into the clouds, COMnews. Retrieved from https://www.comnews.ru/content/112517/2018-04-03/ sberbank-vzletel-v-oblaka. (Accessed 27.11.2020). 
Sberbank transferred part of its branches in Crimea to RNKB, RIA Novosti. Retrieved from https://ria. $\mathrm{ru} / 20140411 / 1003554779 . \mathrm{html}$. (Accessed 27.11.2020).

Sharionov, A.N. The state is in debt: how the savings of citizens in the Savings Bank of the USSR were destroyed accounts. Retrieved from https://www.forbes.ru//mneniya-column/makroekonomika/238749-gosudarstvo-v-dolgukak-unichtozhili-sberezheniya-grazhdan-v-sb. (Accessed 27.11.2020).

State Bank of the USSR Resolution of 15.04.1991 on the payment of the state internal debt.

Statistics showcase: GDP at market prices according to 2008 SNA methodology. Retrieved from https://showdata. gks.ru/report/280029. (Accessed 27.11.2020).

The Central Bank sold Sberbank to the government. Why? And how much was the deal? TASS. Retrieved from https://tass.ru/ekonomika/7737581. (Accessed 27.11.2020).

The United States added three Crimean wineries to the sanctions list, RIA Novosti. Retrieved from https://ria. $\mathrm{ru} / 20151222 / 1346989108 . \mathrm{html}$. (Accessed 27.11.2020).

UN General Assembly Resolution “Territorial integrity of Ukraine” from 27 March 2014 A/RES/68/262.

United Savings business. (1992). R.V. Korneev, Ed. MS: Statistics.

US Ministry of Finance expanded the sanctions list in connection with the crisis in Ukraine, RIA Novosti. Retrieved from https://ria.ru/20151222/1346973194.html. (Accessed 27.11.2020).

Ustav kredytnyi. Svod zakonov Rossiyskoi Imperii. SPb., 1893. T.XI. Ch. II. p. 107.

Voznesensky, N. (2015). The military economy of the USSR during the Patriotic War. Outlines of global transformations: politics, economics, law, 8(3), 6-33.

Western Bank of Scotland: History. Retrieved from https://www.natwestgroup.com/heritage/companies/westernbank-of-scotland.html. (Accessed 25.11.2020)

World Bank National Accounts Data and data files on OECD national accounts, World Bank website. Retrieved from https://data.worldbank.org/indicator/NY.GDP.MKTP.CD? Locale=ru\&locations=RU. (Accessed 23.11.2020).

\title{
Этапы развития Сбербанка как отражение перемен в государстве
}

Олег Григорьевич Новикова, Алексей Маненков

\author{
а Доцент, кафедра политологии, Финансовый университет, Москва, Россия \\ OGNovikov@fa.ru

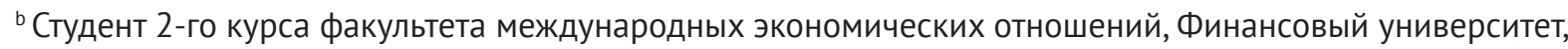 \\ Москва, Россия \\ lexmanenk4@gmail.com \\ 'Студент 2-го курса факультета международных экономических отношений, Финансовый университет, \\ Москва, Россия \\ dagmara.intouch@gmail.com \\ (c) Олег Новиков, Алексей Маненков, Дагмара Борщигова, 2020
}

Аннотация. Исследовательская группа, состоящая из политолога и двух молодых специалистов по международным финансам, провела междисциплинарное исследование Сбербанка, чтобы понять предпосылки его нынешнего состояния. Для этого авторы проверили историю, принципы работы и взаимоотношения Сбербанка с различными политическими институтами, в том числе с национальным государством в качестве главного из них. Авторы обнаружили, что Сбербанк кардинально изменился параллельно со сменой государства - основанный как прозрачное стабильное сберегательное учреждение во времена царской Российской империи, он впитал в себя все противоречия более поздних эпох своим «крещендо» 1990-х гг. В литературе много говорилось о вкладах граждан, сделанных до 1991 г. и позже, заявленных «сожженными» или «обнуленными», но авторы попытались добавить некоторые аргументы, пытаясь представить альтернативные точки зрения и подсчитать масштабы финансовых потерь граждан. Ключевые слова: Сбербанк; депозиты; история Сбербанка 